Sosyoloji Derneği, Türkiye

Sosyoloji Araştırmaları Dergisi

Cilt: 17 Sayı: 2 - Güz 2014

Sociological Association, Turkey

Journal of Sociological Research

Vol.:17 Nr.: 2 - Fall 2014

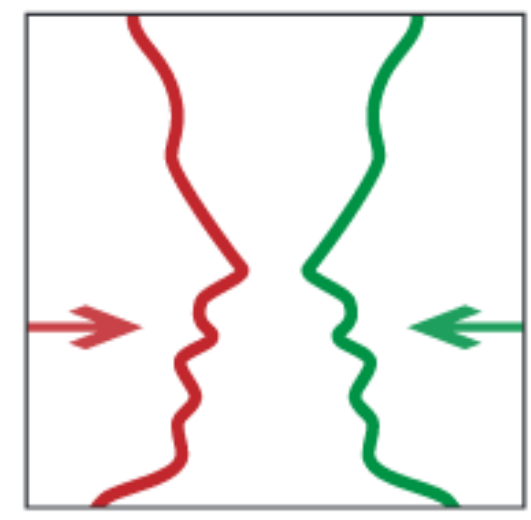

Okul Çağı Çocuklarının Toplumsal Cinsiyet Algıları: Gündelik Yaşam Örnekleriyle Cinsiyetçiliğin Benimsenme Durumuna ve Esneyebilme Olasılığına Dair Bir Araştırma

A. Zeynep Kılıç, Ayşe Beyazova, H. Melda Akbaş, Ayten Zara, İrem Serhatlı 


\title{
Okul Çağı Çocuklarının Toplumsal Cinsiyet Algıları: Gündelik Yaşam Örnekleriyle Cinsiyetçiliğin Benimsenme Durumuna ve Esneyebilme Olasılığına Dair Bir Araştırma
}

\author{
A. Zeynep KILIÇ \\ Ayşe BEYAZOVA ${ }^{2}$ \\ H. Melda $A K B A S^{3}$ \\ Ayten $Z_{A R A^{4}}$ \\ Irem SERHATLI ${ }^{5}$
}

Öz

Toplumsal cinsiyet normları ve kalıpyargılar, çocukların cinsiyet kimliklerini oluşturmada oldukça etkilidir. Bu araştırma, çocukların toplumsal cinsiyet algılarını ve algıların dayandığı cinsiyetçi kalıpyargıları açığa çıkarmak amacıyla yapılmıştır. Araştırmanın hedeflerinden biri de farklı yaş gruplarının, bu kalıpyargıların nasıl ve hangi araçlarla kırılabileceğine ya da esneyebileceğine dair görüşlerini almaktır. Araştırmadan çıkan bu veriler, çocuklarda daha eşitlikçi bir toplumsal cinsiyet algısı geliştirmek için hazırlanan bir eğitsel oyuna zemin hazırlamıştır. Araştırma kapsamında, 7-15 yaş arasında, ilköğretim öğrencisi olan 33’ü kız, 33’ü erkek olmak üzere toplam 66 çocukla odak görüşmeler yapılmıştır. Görüşmelerin sonuçları BEM ölçeğinden yararlanılıp, çocukların ifadelerinden oluşan güncel bir kavramlar listesi üzerinden değerlendirilmiştir. Bulgulara göre, çocukların toplumsal cinsiyet algısının yaş dönemine göre değiştiği, bununla birlikte erkek olmanın her dönemde daha değerli görüldüğü söylenebilir. Kadınlık rollerinin ifade edilen tüm zorluklarına rağmen, iki cinsiyet grubunun da yetişkin dönemde alınan sorumlulukların önemi açısından erkek olmanın daha zor olduğunu ifade etmesi, toplumsal cinsiyet algısının etkinliğini göstermektedir.

Anahtar Kelimeler: Toplumsal cinsiyet, Çocuklarda cinsiyet algısı, Cinsiyet rolleri, Kalıpyargilar

\footnotetext{
${ }^{1}$ Dr. İstanbul Bilgi Üniversitesi, Çocuk Çalışmaları Birimi.

2 Öğr. Gör. İstanbul Bilgi Üniversitesi, Çocuk Çalışmaları Birimi.

${ }^{3}$ İstanbul Bilgi Üniversitesi, Çocuk Çalışmaları Birimi.

${ }^{4}$ Yard. Doç. Dr. İstanbul Bilgi Üniversitesi, Psikoloji Bölümü.

5 İstanbul Bilgi Üniversitesi.
} 


\title{
Gender Perception of School Age Children: A Study on How to Break Children's Gender Stereotypes by Using Daily Examples
}

\begin{abstract}
Gender norms and stereotypes affect children's gender identity construction. This research is aimed to uncover children's gender perceptions and gender stereotypes. This research also aimed to find out how to break children's gender stereotypes by using daily examples. The data collected from this research were used to develop an educative game to improve children's gender perceptions. In order to collect data, a number of focus interviews were done with 33 girls and 33 boys between the ages from 7 to 15 . The children's perceptions were evaluated according to an updated scale, constructed due to children's expressions, by being derived from the BEM scale. The findings indicated that children's gender perceptions differ from age to age; but for all ages to be man is more valuable than to be a girl. Despite the expressions regarding the difficulty of being female, all students found more difficult to be a male because of the responsibility taken in adulthood. This interesting and conflicting result shows the strength of gender roles in children's perception.
\end{abstract}

Key words: Gender, Gender roles, Children's perception of gender roles, Stereotypes 


\section{Giriş}

Yaşadığımız dünya ve toplumumuz pek çok ayrımcılık içeriyor. Cinsiyet ayrımcılığı bunlardan biri, belki de en temeli. Aynı hayatı yaşadıkları halde, kadın ve erkeklerin hayat algısı birbirinden ayrı; işleri, sorumlulukları, dertleri, korkuları farklı. Bu farklılık çocukluktan itibaren kurulan ve sosyal çevreyle sürekli beslenen cinsiyet ayrımcılığının sonucu olarak ortaya çıkıyor. Bir yakınımızın bebek beklediğini öğrendiğimizde ilk merak ettiğimiz şey cinsiyeti. O bebeğe dair bütün beklentimizi bu bilginin üzerine kuruyoruz. Ne giyecek; nasıl hareket edecek; nelerden keyif alıp nelerden uzak duracak; hangi okula gidip ne tür bir iş yapacak; kaç yaşında evlenip ne tür bir aile kuracak... Ve tüm çocuklardan da bu beklentiyi karşılamalarını bekliyoruz. Karşılamayanların ya da karşılamak istemeyenlerin başına türlü çeşit işler geliyor. Çocuklar, çocukluk dönemleri boyunca, yetişkinlerin onlara yüklediği bu ayrımcı beklentiler ve sağladığı sınırlı olanaklar içinde, kişiliklerinin en önemli unsuru olan cinsiyet kimliklerini geliştirmek için uğraşıyorlar. Peki çocuklar bu konuda ne düşünüyor? Bu ayrımcılığı fark ediyorlar mı? Durumlarından memnunlar mı ya da değiştirmek istiyorlar mı? $\mathrm{Bu}$ makale, bu alanda çocuklarla yapılan küçük bir araştırmanın sonuçlarını aktarıyor. Çocukların gündelik yaşamları ve sosyal ilişkileri üzerinden toplumsal cinsiyet ayrımcılığını nasıl yaşadıklarını, ayrımcılığı aktaran kalıpyargıları nasıl algıladıklarını, bunları dönüştürme isteklerini ve bunun için araçlarının neler olduğunu ortaya çıkarmaya çalışıyor. Daha da önemlisi çocukları bu alanda desteklemek için çevrelerindeki yetişkinlerin neler yapabileceğini tartışıor.

\section{Toplumsal Cinsiyet Öğrenilir}

Toplumsal cinsiyet kavramı, başta kadın ve erkek olmak üzere tüm cinsel kimliklere yönelik olarak toplumda yer alan alg1, beklenti ve davranışlar setini ifade eder. Toplumsal olarak kurulduğu ve kurgulandığı için sadece biyolojik cinsiyete değil aynı zamanda yaş, coğrafi bölge, sınıf, etnik / dinsel kimlik, siyasal / ideolojik görüş, cinsel yönelim, medeni durum, engellilik durumu gibi pek çok unsura bağlı olarak oluşur. Sosyolojik bir ifadeyle toplumsal cinsiyet, erkek ve kadın bedenlerini tanımlayan anatomik ve fizyolojik farklardan değil, Chodorow'un 1970'lerde dikkatimizi çektiği gibi, kadın ve erkeklerin sosyal çevresi ve bunun içinde edindikleri deneyimle ilgilidir (Chodorow, 1974). Dolayısıyla toplumsal cinsiyet, biyolojik cinsiyet farkından ziyade, psikolojik, toplumsal ve kültürel farklarla beslenir. Ve yine 
bu nedenle, asıl olarak toplumsal iktidar ilişkilerinin nasıl şekillendiğini analiz etmeye yarar. Sadece toplumsal yapılar düzeyinde değil, bireysel ilişkiler düzeyinde de bu analizi yapabilmek mümkündür.

Toplumsal düzeyde yapılan analiz, günümüz toplumlarının erkek egemenliğine dayalı toplumlar olduğunu gösterir. Bunun anlamı, aralarında yukarıda bahsedilen farklılıklar olsa da, erkeklerin kadınlar aleyhine avantajda olduğu, toplumsal sonuçlardan kadınlara oranla daha fazla yararlandıkları bir toplumsal düzenin sürdüğüdür. ${ }^{6}$ Bu toplumsal düzenin iki temel özelliği vardır. Birincisi, cinsiyete dayalı işbölümüne dayanıyor olmasıdır. Yani toplumun sürmesi ve gelişmesi için yapılması gereken işler kadınlar ve erkekler arasında, isteklerine ya da becerilerine göre değil, biyolojik cinsiyetlerine göre paylaştırılmıştır. Bu paylaşım kesindir, değişmemesi toplum yararınadır! İkincisi ise şudur: Toplumda "norm” olan erkektir, kadın ise bu normlara uyması gereken, ama erkek olmadığı için hiçbir zaman uyamayacak olandır; "kuraldan sapma"dır (Gilligan,1987). Bu yüzden, erkek egemen toplumda işler "eşit" bölüşülmüş olsa da, kadına verilen rol ve atfedilen değer ikincildir.

Bununla birlikte, 1980'lardan itibaren literatüre giren "hegemonik erkeklik", toplum içinde tüm erkeklerin “norm” u oluşturduğu ve aynı iktidara sahip olduğu yanılgısına düşmemizi engeller. Hegemonik erkeklik, "iktidarı elinde tutan erkeklerin sahip olduğu erkeklik imgesi”ni tanımlar (Sancar, 2009:30). Dolayısıyla erkek egemen toplum içinde, farklı sosyal çevrelere mensup olan erkekler ki aslında erkek nüfusunun çoğunluğudurlar, kadınlar kadar olmasa da, iktidarın uzağındadırlar. Bununla birlikte, katılarak, onaylayarak ya da susarak sürmesine olanak sağlamaları karşılığında bu “erkeklik imgesi”nden pay alırlar, kadınlardan farklı ayrıcalıklara sahip olurlar. Bunların başında, kadınları ikincilleştirebilme, kendi iktidarını kadınlar üzerinde uygulayabilme ayrıcalığı gelir. "Evin reisi” olma, cinsel hazzı açık ve meşru biçimde yaşama, şiddet uygulayınca hoş görülme gibi ayrıcalıklar erkeklere aittir. Hegemonik erkekliği kuran ve sürdüren, kadınlar üzerinden oluşturulan çıkarlara dayalı işbirliğidir (Connell, 1998).

\footnotetext{
${ }^{6}$ Lgbti bireyler açısından bu genelleme doğruluk payı taşımayabilir. Cinsel yönelim, toplumsal cinsiyet kavramsallaştırmasının önemli bir parçası olsa da, bu araştırma kapsamında konu dışında bırakıldığından kavramsallaştırma aşamasında da üzerinde durulmamıştır. Bunun, araştırma ve makalenin sınırlılıklarından biri olduğunun altı çizilmeli ve çocukların Igbti bireylere yönelik algılarına dair araştırmaların da yapılması gerektiği önemle belirtilmelidir.
} 
Toplumsal düzeydeki bu yapının devam edebilmesi, bireysel düzeyde benimsenmesini zorunlu kılar. Hem kadınlar hem erkekler için, erkek egemen toplum düzenine uygun davranmayı “öğrenmek” zorunludur. Bu öğrenme, gündelik pratikler ve kültürel alışkanlıklarla olduğu kadar, bizatihi eğitim sistemiyle de gerçekleşir. Öğrenme yaşam boyu sürüyor olsa da, asıl hedef kitle çocuklardır. Basitçe ifade etmek gerekirse her çocuk, cinsiyete dayalı işbölümünü, bundan üzerine düşen sorumluluğu, eğer kadınsa ikinci sırada durmayı, eğer erkekse hegemonik erkeklikle işbirliği yapmayı öğrenmek zorundadır. Buradan itibaren toplumsal cinsiyet rolleri olarak ifade edilecek bu öğrenmenin alanları, ev (aile), okul ve sokak ile medyayı da içerecek biçimde çocuğun sosyal çevresidir. İzleyen bölümde, çocuğun gelişimi boyunca toplumsal cinsiyet rollerini nasıl öğrendiği detaylandırılacaktır.

\section{Çocuk Gelişimi İçinde Toplumsal Cinsiyetin Etkisi}

Toplumlarda kadınlara ve erkeklere özgü olduğu düşünülen davranışlar ve sorumluluklar, yani toplumsal cinsiyet rolleri ve rolleri ifade eden kaltpyargılar toplumsal cinsiyet algısının aktarımında çok önemli rol oynar. Cinsiyetçi kalıpyargılar kadın ve erkeklere yönelik kesin olduğu düşünülen, genellenmiş, yaygın kanı ve düşüncelerdir. Bunun sonucunda, toplumsal olarak kurulan, kadının ve erkeğin doğasıyla (anatomik ve fizyolojik yapıyla) doğrudan bağlantısı olmayan cinsiyet rolleri, doğalmış ve veriliymiş gibi görülür. Bu rolleri yerine getirdikçe kişi toplum tarafından takdir edilir ve böylece roller toplumsal takdiri kazanmak, toplumsal dışlanmadan kaçınmak güdüsüyle değişmeyen ve katılaşan bir form halini alır (Butler, 1990). Toplumsal takdir kazanma ihtiyacı çocuklarda yetişkinlerden daha fazla olduğundan, çocukluk cinsiyet rollerinin öğrenilmesi için en uygun dönemdir.

Üstelik, çocuk gelişiminin önemli evrelerinden biri, cinsiyet kimliğinin oluşmasıdır. Hatta, toplumsal cinsiyet öğrenilen ilk toplumsal kategoridir (Cowan \& Hoffman, 1986; Leinback \& Fagot, 1993; Levy \& Haaf, 1994). Çocuk gelişiminin önemli evrelerinden biri, cinsiyet kimliğinin oluşmasıdır. Hatta, toplumsal cinsiyet öğrenilen ilk toplumsal kategoridir (Cowan \& Hoffman, 1986; Leinback \& Fagot, 1993; Levy \& Haaf, 1994). Cinsiyet kimliğinin oluşmasının bir boyutu çocuğun bedenini ve cinselliğini keşfetmesiyse, diğer boyutu cinsiyetine uygun olarak gördüğü rolleri benimsemesidir. Bilişsel teori, çocukların kendilerini çevreleyen dünyayı anlamlandırmak için etkin biçimde arayış içinde olduğunu ve bunun için 
toplum tarafindan sağlanan her tür işaretin, gördüklerini ve duyduklarını yorumlamalarına yardımcı olduğunu varsayar. Bu anlamda çocuk gelişirken, pasif bir alıcı olmaktan çok etkin olarak kendi dünyasının oluşumuna katkı sağlar.

Toplumsal cinsiyet gelişimi ile ilgili ilk bilişsel teori Piaget'den hareketle Kohlberg'in (1966) geliştirdiği bilişsel gelişim yaklaşımıdır. Kohlberg, çocuğun toplumsal cinsiyet gelişiminde etkin rolüne vurgu yapar ve çocuğun toplumsal cinsiyet algısının kendi davranışlarını etkilediğini; hatta bu etkinin çocuk, cinsiyetin sabit ve değişmez olduğu gibi daha sofistike bir toplumsal cinsiyet anlayışına sahip oldukça daha da güçlendiğinin altını çizer. 1970ler'de toplumsal cinsiyete yeni bir bilişsel yaklaşım gelişmiştir: Toplumsal Cinsiyet Şeması Teorisi (Gender Schema Theory). Bu teori, çocukların yapılandırılmış toplumsal cinsiyet temelli kavramlardan oluşan şemalar düzenlediği ve bu şemanın çocukların düşüncelerini ve davranışlarını etkinlediği düşüncesine dayanır. Toplumsal Cinsiyet Şeması Teorisi, sosyal ve gelişimsel psikologların katkılarıyla gelişmiştir (Liben \& Bigler, 2002; Martin, Ruble, \& Szkrybalo, 2002). Bugün gelinen aşamada, toplumsal çevrelerinin doğasına ve cinsiyet hakkındaki kendi görüşlerine bağlı olarak, çocukların toplumsal cinsiyet kimliğini etkin biçimde kurguladıkları görüşü ön plandadır.

Psikolojik gelişim açısından bakıldığında, çocuklar genel olarak toplumsal cinsiyet kimliğini, kendi toplumsal cinsiyetleri ile diğerlerininkini "doğru” olarak tanımlama becerisini, 2-3 yaşında edinmekte; cinsiyet kesinliğini yani insanların yaşamları boyunca aynı cinsiyete sahip olacakları gerçeğini, 4 yaş civarında geliştirmekte ve cinsiyet sürekliliğini yani insanların görünüşü değişince cinsiyetlerinin değişmediğini, 5-6 yaş civarında anlamaktalar (Bee ve Boyd, 2007). Dolayısıyla çocuk 5 yaşına geldiğinde, kendi çevresinde var olan, hem kendisi hem diğerleri için kullandığı etkileyici, sıklıkla eğlendirici ama temelde yanlış olan cinsiyetçi kalıpyargılar setini edinmiş olur. $\mathrm{Bu}$ kalıpyargıları diğerleri hakkında izlenimlerini şekillendirmek, kendi davranışlarına rehberlik etmek, dikkat çekmek ve hatıraları organize etmek için kullanır (Martin ve Ruble, 2004). Bu anlamda kalıpyargılar, çocuğun yaşadığ1 dünyayı ve kendini anlamlandırmakta yol gösterecek kuralları ve düzeni oluşturmasının bir parçasıdır; yaşadığı çevreye uyum sağlamasını kolaylaştıran bir unsurdur. Öyleyse, çocuğun gelişimi boyunca çevresindeki toplumsal cinsiyetçi işaretlerin ve kalıpyargıların azalması ya da bunları sorgulayıcı bir yaklaşımın benimsenmesi, çocuğun da cinsiyetçi eğilimlerinin azalmasını kolaylaştıracaktır. 
Bandura (1991) çocukların içine doğdukları dünyayı gözlemleyerek ve taklit ederek, uygun ve beklenen davranışları öğrendiklerini ifade eder. Dolayısıyla çocukların ilk sosyalleştiği alan olan ailede gördükleri, ilerde çocuğun normlarının oluşmasında oldukça etkili olacaktır. Cinsiyet rolleri ise, anne ve babanın evdeki rol dağılımının gözlemlenmesi ve cinsiyete dair hangi özelliklerin makbul görüldüğüyle kazanılır. Böylece, gelişimsel olarak ailede başlayan sosyal-öğrenme ile toplumda nasıl davranması gerektiğini belirleyecektir. Ancak bunun oluşmasında sosyal normların yanında, bilişsel gelişim de etkendir. Nitekim, yapılan çalışmalar cinsiyet rollerine dair kalıpyargıların özellikle ailede eşlerin cinsiyetçi davranışlarına göre belirlendiğini göstermektedir. 2 yaşındaki çocuklar belli görev ve durumları erkek ve kadın cinsiyle birleştirmeye başlamaktadır. Mesela yemek yapmak, ev temizlemek kadınla, arabalar ve aletler erkekle eşleştirilmektedir. Çocuklar 3-4 yaşından itibaren kalıpyargısal olarak meslekleri, oyuncakları ve etkinlikleri cinsiyete göre algılamakta (Ruble ve Martin, 1998; Signorella, Bigler ve Liben, 1993); 5 yaştan itibaren ise belli karakter özelliklerini erkeksi ve kadınsı olarak tanımlamaya başlamaktadırlar. Bu süreç 8-9 yaşında tamamlanmakta ve toplumsal cinsiyet rollerine dair bilgi tam olarak gelişmiş olmaktadır (Martin, 1993). Bu yaşlarından itibaren birçok çocuk kalıpyargılardan uzaklaşmakta ve cinsiyet rollerine daha esnek bakabilmektedir. Bazı eylemlerin ya da davranışların belli bir cinsiyet tarafından daha sık gerçekleştirildiğini görseler bile, bunların her iki cinsiyete de açık olduğunu kabul etme eğilimleri artar. Çocukların kalıpyargılara ilişkin bilgisi, kişilik özelliklerinde, akademik becerilerde, mesleklerde, toplumsal motivasyonlarda ve davranışlarda daha fazla çeşitlilikle karşılaştıkça, ergenlik döneminde gelişmeye devam eder (Tobin et. Al., 2010). Ergenlikte toplumsal cinsiyet rollerine dair kalıpyargılar, bireysel farklılıkların ya da ayrıksı durumların fark edilmesiyle esneklik kazanmaya başlar (Carter \& Patterson, 1982; Eccles, 1987; Katz \& Ksansnak, 1994; Stoddart \& Turiel, 1985). Ancak bilgi düzeyindeki bu esnekliğe rağmen, cinsiyet rollerine uygun davranmaya yönelik toplumsal beklenti, ergenlerin davranışlarında etkili olur. Bu dönemde özellikle cinselliğin ve karşı cinsle ilişkilerin artması da var olan kalıpyargılara uygun davranmayı destekler, hatta çoğu durumda güçlendirir (Hill \& Lynch, 1983; Simmons \& Blyth, 1987). 
Toplumsal cinsiyet farklılığının neden olduğu ilk ayrımcılık, kalıpyargılar aracılığıyla bireyleri belli kalıplara sokması ise bir diğeri iki cinsiyete atfedilen değerler ve özellikler arasında bir hiyerarşi yaratmasıdır. Dolayısıyla çocuklar bir yandan kadınlık ve erkeklik durumunun farklılıklar içerdiğini görür ve buna uygun davranışlar sergilemeye çalışırken, bir yandan da erkeksi kalıpyargıların hiyerarşik olarak daha üstün olduğunu da öğrenirler (Ruble \& Martin, 1998). Erkeklere güçlü (iktidar içeren) erkeksi özellikler, kadınlara bağımlılık ifade eden kadınsı özellikler atfedilir olur. Ayrıca, giderek bu ayrımın biyolojik olmaktan çok toplumsal nedenlere dayandığı algılansa bile bu durum değişmez. Örneğin çocuklar, bilmedikleri bir mesleğin erkekler tarafından yapıldığı söylendiğinde, doğrudan daha yüksek bir statü verirler (Liben, Bigler ve Krogh, 2001). Üstelik bu durum, toplumdan topluma farklılık göstermez. Bee ve Boyd (2007)'un, 24 farklı ülkede çocukların cinsiyetçi kalıpyargıları üzerine yürüttüğü çalışma, kalıpyargıların büyük benzerlikler taşıdığını göstermektedir. Örneğin, 8 yaşındaki çocuklar hikâyelerdeki erkek figürü saldırganlık, güç, zalimlik, hantallık ve gürültü ile tanımlarken kadın figürü zayıflık, naziklik, kadirbilirlik ve yumuşak kalplilikle eşleştiriyor. Çalışma, ayrıca 9-10 yaşından küçük çocuklarda, bu dönemde cinsiyet rolleri çok keskin olduğu için, androjen cinsiyet rolü ile çok az karşılaşıldığını; kızların erkeklerden daha çok androjen tipine girdiğini; yine kızların, erkeklerin kadınsı niteliklerinden daha fazla erkeksi nitelikler taşıdıklarını göstermiştir. Androjen ya da erkeksi nitelikler taşıyan erkek ve kızların daha fazla özdeğerliliğe sahip olduğu saptanmıştır ki, bu sonuç kadınsılığa verilen değeri göstermek açısından oldukça çarpıcıdır (Bee ve Boyd, 2007) ve hegemonik erkeklik açısından da oldukça anlaşılırdır (Connell, 2000). Hegemonik erkeklik, kültürel anlamda güç ve saygınlık sahibi olmayı getirir. Bir kadının bu saygınlığa yaklaşabilmesi ancak erkeksi özelliklere sahip olmasıyla mümkündür. Çocukların, erkeksi özellikleri daha üstün bulmalarındaki bu kültürel normlar sürdürülecek araştırmalarda dikkatle incelenmelidir.

Çocuklarla yürütülen toplumsal cinsiyet araştırmaları; cinsiyete dayalı işbölümünün belirlenmesi; oyun, spor, boş zaman alışkanlıklarının ya da eğitim ve meslek seçiminin "cinsiyetinin" değerlendirilmesi gibi çocukların yaşamlarında belirleyici olan farklı alanları da kapsamaktadır. Konunun kapsamının genişliğine rağmen, bu konuda yürütülen araştırmaların görece az olduğunu belirtmekte yarar vardır. 


\section{Okul Çağı Çocuklarının Toplumsal Cinsiyet Algıları Araştırması}

Araştırmanın amacı, ilköğretim çağı yaş grubundaki (7-14) çocukların toplumsal cinsiyet algılarını ortaya çıkarmak, bu algıların ne ölçüde kalıplaşmış olduğunu, kalıpların hangi noktalarda esneyebilme olasılığı taşıdığını belirlemektedir. Bir başka ifadeyle çocukların yaşamlarında maruz kaldıkları cinsiyetçi kalıpyargılara, bu kalıpyargıların nedenlerine yönelik farkındalıklarına ve bu kalıpyargıların nasıl esneyebileceğine/ kırılabileceğine odaklanan bir çalışma yapılmıştır. Araştırma için okul ve ilk ergenlik çağının tercih edilmesinin birinci nedeni, araştırmacıların bu yaş grubu ile çalışmaya alışık olmalarıdır. Bu nedenle daha küçük yaş grubu daha farklı bir yöntem ve uzmanlık gerektirdiği için kapsam dışı bırakılmıştır. Bu dönemde çocukların kendilerini ifade edebilme, arkadaşlarıyla tartışabilme ve sosyal çevrelerini anlatabilme, hatta analiz edebilme becerilerinin artıyor olması tercih edilmelerinde önem taşımıştır. Okul çağı, çocukların toplumsal cinsiyet algılarının oturduğu ama değişim gösterdiği ve seçilen yaş grubu içinde yukarıda anlatıldı̆̆ 1 biçimde farklı algı dönemlerini analiz etmeyi de kolaylaştıran bir dönem olarak tercih edilmiştir. Ayrıca araştırma bulguları, çocukların cinsiyetçi rollere yönelik farkındalıklarını artırmayı hedefleyen bu yaş grubuna yönelik eğitsel oyunlara ${ }^{7}$ veri sağlamak amacıyla kullanıldı̆̆ı için, özellikle "esneme noktaları"nın neler olduğunu ve gelişme çağına göre nasıl farklılaştığını belirlemek hedeflenmiştir.

Araştırmanın önemi, çocuklarla yapılan toplumsal cinsiyet araştırmalarının çoğundan farklı olarak psikolojik değil, sosyolojik bir yaklaşım içermesidir. Ayrıca, çocuk hakları bakış açısını odağına yerleştirmesi nedeniyle de önemlidir. Çocuk hakları yaklaşımı, hem yöntemin ve araştırma içeriğini belirlenmesi sürecinde hem de bulguların değerlendirilmesinde ön planda olmuştur. Daha açık bir ifadeyle yapılan iş, çocukların katılımı ve öncelikli yararı gözetilerek, araştırmaya katılan çocuklara, hak sahibi bireyler olarak yaklaşılarak sürdürülmüştür. Araştırma sonucunda elde edilen bulgular, çocuklarla toplumsal cinsiyet eşitliği konusunda çalışmayı amaçlayan eğitim materyallerinin geliştirilmesinde kullanılması da, çocuk haklarının gelişmesine yönelik bir katkı sağlamayı hedeflemektedir. Şiddet gibi yıkıcı bir olgunun altında sosyo-kültürel etmen olarak cinsiyetçi rollere dair katılaşmış kalıpyargıların olduğunu,

${ }^{7}$ Geliştirilen eğitim materyalleriyle ilgili ayrıntılı bilgi için bkz: http://www.cocukcalismalari.org/project/toplumsal-cinsiyet-esitligi-projesi/ 
saldırganlığın babadan oğula, mağduriyetin anneden kıza toplumsal olarak geçtiğini düşündüğümüzde, bu araştırmanın ve sonuçları doğrultusunda ortaya çıkan eğitsel materyallerinin önemi de kavranacaktır.

Araştırma aşağıdaki sorular kapsamında şekillendirilmiştir:

- İlköğretim çağındaki çocukların bakış açısına göre kız ve erkek olmak nasıl farklılaşıyor?

- Kız ve erkek çocukların aynı yaş düzeyindeki gündelik yaşam deneyimleri cinsiyete göre nasıl farklılaşıyor?

- Çocuklar tüm bu farklılıkları değerlendirirken değerlendirmelerini cinsiyetçi yargı ve tutumlara dayandirıyor mu?

- Çocukların sahip oldukları cinsiyetçi yargı veya tutumlarını esnetebildikleri noktalar neler?

\section{Yöntem}

\section{Örneklem}

Araştırma, İstanbul'un Eyüp ilçesinde bir ilköğretim okulunda, Mayıs - Temmuz 2012 tarihinde yürütülmüştür. Katılımcı çocuklar öğretmenler aracılığıyla belirlenmiş olmakla birlikte, araştırma öncesinde araştırmacılar tarafından bilgilendirilmiş ve gönüllü katılımları sağlanmıştır. Araştırma, okul saatleri içinde yürütüldüğü için ailelerden ayrıca bir izin alınmamış, okul müdürü ve öğretmenlerin onayı yeterli görülmüştür. İstanbul Eyüp Silahtarağa İlköğretim Okulu öğrencileri olan 7-15 yaş arası 33 kız, 33 erkek toplam 66 çocuk ve 3 kadın,3 erkek 6 öğretmen katılmıştır.

Araştırma, dört ayrı yaş grubuyla (1.-2.sınıf, 3.-4. sınıf, 5.-6. sinıf ve 7.-8. sınıf öğrencileri) ve her yaş grubunda kız, erkek ve karma grupların yer aldığı toplam 12 odak görüşme ile gerçekleştirilmiştir. 1.-2. sınıf grubunda 4'er, diğer gruplarda 6'şar çocuğun katılımıyla gerçekleşen odak görüşmelerde 33 kız, 33 erkek toplam 66 çocuğa ulaşılmıştır.

\section{Veri Toplama}

Araştırma yöntemi olarak niteliksel bir yöntem tercih edilmesinin nedeni araştırmanın çocukların algı ve görüşlerini odağa alma kaygısından kaynaklanmaktadır. Çocukların kendi sözleri ile görüşlerini ifade etmelerini sağlamak öncelikli amaç olduğu için yarı yapılandırılmış açık uçlu soru formlarıyla görüşme yapılması tercih edilmiştir. Birebir görüşme yerine odak görüşmenin tercih edilmesinin nedeni ise, toplumsal cinsiyetin sosyalleşme aracılığıyla gelişen 
ve yerleşen bir durum olmasından hareketle, çocukların kendi sosyal çevrelerinde bu konuyu tartışmalarının daha verimli sonuçlar vereceğinin düşünülmesidir. Özellikle araştırmadan elde edilecek bulguların çocukların toplumsal cinsiyet algılarını geliştirecek eğitsel bir oyuna veri sağlayacak olması onları etkileşim içine sokmanın gerekliliğini arttırmıştır.

Çocuklarla yapılan görüşmeler BEM ölçeğinden ${ }^{8}$ yararlanılarak kodlanmış; değerlendirme bu kodlar ve aşağıda bahsedilen kategoriler üzerinden yapılmıştır. Bu ölçek çocukların cinsiyetlere dair tanımlarına karşılık geldiği ve üzerinden değerlendirme yapmaya imkan sağladığı için işlevseldir. Ancak araştırmada, biraz daha farklı bir yol izlenmiş, çocuk hakları yaklaşımına uygun olarak çocukların ifadelerine sahip çıkmak hedeflendiği için, görüşmelerde çocukların yaptığı tanımlamalar ile yeni bir kod listesi oluşturulmuştur. Örneğin, 'hanım hanımcık' kavramı, ilk hareketi erkekten bekleyen ve terbiyeli olma hali ile feminen ölçeğinde kullanılmıştır. Bir başka örnek de, 'otoriter' kavramının, keyfi davranabilme ve kuralları koyma hali ile maskülen ölçekte ortaya çıkmıştır. Bu listedeki ifadelerin hepsinin çocukların ifadeleri olduğunun altını yeniden çizmekte yarar vardır.

\section{Araştırmanın Yürüttülmesi}

Araştırma çocukların katıldığı odak görüşmelerle gerçekleşmiştir. Katılacak çocukları öğretmenler belirlemiş; ancak araştırma öncesinde tüm çocuklar araştırmacılar tarafından bilgilendirilmiş ve gönüllü katılımları önemsenmiştir. Araştırma okul içinde yürütüldüğünden, ailelerden ayrıca izin alınmamış, okul müdürü ve öğretmenlerin onayları yeterli görülmüştür.

Çocuklarla yapılan odak görüşmeler, yukarıda belirtildiği gibi dört ayrı grupla (7-8 yaş / 1.-2.sınıf, 9-10 yaş /3.-4. sınıf, 11-12 yaş/5.-6. sınıf ve 13-15 yaş/7.-8. sınıf) ve her grup için kız, erkek ve karma olmak üzere üçer kez gerçekleşmiştir. Hem tek cinsiyetli hem karma grupların organize edilmesinin nedeni, toplumsal cinsiyet durumunun farklı sosyal ortamlarda nasıl görünür olduğunu tespit etmek içindir. Nitekim hedeflendiği gibi tek cinsiyet gruplarından

\footnotetext{
${ }^{8}$ Bem Cinsiyet Rolleri Envanteri, (Bem, 1974), Bem Cinsiyet Rolleri Envanteri’nin Türkçeye uyarlanması Kavuncu (1987) tarafından yapılmış olup, envanterin Kadınsılık ve Erkeksilik ölçekleri, kadınsı ve erkeksi özellikleri ölçen 20'şer sıfattan oluşmaktadır. Envanterin Kadınsılık ve Erkeksilik ölçeklerinden eldeedilen puanlara göre kişilerin cinsiyet rolleri belirlenmektedir. Ölçeğin Türkçe formunun onbeş gün araylauygulanması sonucu hesaplanan test-tekrar test güvenirlik katsayısı Kadınsılık için .75, Erkeksilik için .89 bulunmuştur.
} 
çok karma gruplarda etkileşim sağlanmış, her yaş düzeyinde kız ve erkek öğrenciler arasında anlamlı tartışmalar yürütüldüğü görülmüştür.7-8 yaş/1-2. sınıf grubunda, odak gruba katılım sayısı, çocukların kendilerinin daha rahat hissedecekleri ve ifade edecekleri bir görüşme ortamı yaratmak amacıyla 4 olarak belirlenmiştir. Dolayısıyla bu yaş grubunda yürütülen üç odak görüşmede, 6 kız - 6 erkek toplam 12 çocuğun görüşleri alınmıştır. Diğer üç yaş grubunda odaklara katılım sayısı 6 olmuştur. Bu gruplarda görüşleri alınana toplam çocuk sayısı 9 kız 9 erkek olmak üzere 18'dir. Toplamda 12 odak görüşme gerçekleştirilmiş ve 33 kız, 33 erkek toplam 66 çocuğa ulaşılmıştır.

Odak görüşmeler okulun, derslerin boş geçtiği son dönemlerinde yapılmıştır. Böylece çocuklar derslerinden alınmamış, boş derslerde eğlenmeyi tercih eden çocuklar da görüşmelere katılmamıştır. Görüşmelerin bir ders saati (40 dk.) sürmesi planlanmıştır. Ancak bazı görüşmeler 60 dakikaya kadar uzamıştır. Bazı görüşmelerde çocukların birbiriyle etkileşimi zayıf kalmış, bu yüzden odak görüşmeden çok toplu birebir görüşme şeklinde yürümüştür. Ancak çoğunluğu, hedeflendiği gibi, çocukların birlikte konuyu tartıştıkları görüşmeler olmuştur. Bunda çocukların birbirlerini tanıyor olmalarının etkisi büyüktür. Altı çizilmesi gereken bir başka konu da, eğitim sistemi içinde görüşleri nadiren sorulan ve okul içinde ders dışında başka tür etkinliği de nadiren yapabilen çocuklar için odak görüşmelerin çok keyifli ve tekrarı istenen bir etkinlik olarak görülmesidir.

Odak görüşmelerin içeriği, 3 temel mekanda çocukların toplumsal cinsiyet algılarını belirlemek üzere biçimlendirilmiştir. Bu 3 mekan çocuğu cinsiyet rollerini öğrendiği ve deneyimlediği temel mekanlar olan Ev, Okul, Sokak olarak tespit edilmiştir. İncelemenin mekan temelinde yapılması, çocukların yaşamlarına odaklanmayı kolaylaştırmış, böylece kendi deneyimlerini ve gözlemlerini aktarmalarını sağlamıştır. Bu mekanlar çocukların temel sosyalleşme alanları olduğu gibi aynı zamanda toplumsal cinsiyetçi kalıpyargıların yaygınlaştığı ve yeniden üretildiği temel mekanlardır. Bu alanlar aynı zamanda çocuklar için özel/kamusal alan ayrımına da karşılık geldiği için; arada bir fark olup olmadığını değerlendirmek açısında işlevsel olmuştur.

3 temel mekanda çocukların;

- k1z/erkek olmak

- toplumsal işbölümü ve ev içi emek 
- çalışma / meslek tercihleri

- oyun / boş zaman etkinlikleri

- okul içi davranışlar ve öğretmenle ilişkiler

- akranlarla ilişkiler / sevgililik halleri ile ilgili kategorilerde görüşleri alınmıştır.

Küçük yaş grubuyla (7-10 yaş) gerçekleştirilen odaklarda önceden hazırlanmış senaryolar kullanılmıştır. Senaryolar araştırma danışmanı ve okulun rehber öğretmeninin desteği ile hazırlanmış, araştırma öncesi yapılan pilot görüşmeler ile etkinliği deneyimlenmiştir. Senaryolar özellikle 7-8 yaş grubunda tartışmaların başlamasına ve açılmasına büyük katkı sağlamıştır. Büyük yaş grubu (11-15 yaş) için bu senaryoları kullanmak gerekmediği yapılan pilot görüşmelerle tespit edildiğinden, tartışma açıcı belli sorular formüle edilmiştir. Aşağıda klz/erkek olmak, toplumsal işbölümü-ev içi emek ve çalışma / meslek tercihleri ile akranlarla ilişkiler / sevgililik durumu başlıkları altında, araştırma bulgularının değerlendirilmesi ve tartışılması bulunmaktadır.

\section{Bulgular}

\section{Kı/Erkek Olmak}

Kız erkek olmak, çocukların toplumsal cinsiyet algıları içinde kendi varlık hallerini değerlendirdikleri kategoridir. Kendi kadınlık / erkeklik durumlarının yanı sıra, toplumda algıladıkları ve zaman zaman idealleştirdikleri kadınlık ve erkeklik durumlarına yönelik görüşleri bu kategori altında değerlendirilmiştir.

Bu kategorideki bulgular çocukların toplumsal cinsiyet algılarını genel olarak yansıtmakta ve literatürde yer alan çocuk gelişimi evreleriyle uyum göstermektedir. Buna göre 6-7 yaş grubunda cinsiyet ayrımı ve buna bağlı işbölümü doğal ve net olarak görülmekte, yaş büyüdükçe bu netlik yerini kafa karışıklığına ve daha esnek bir bakış açısına bırakmakta; toplumsal kurgu fark edilmeye başlanmaktadır. Ergenlik dönemiyle birlikte (11-15 yaş) cinsiyet ayrımı yeniden kesinlik kazanmaya ve giderek keskinleşmeye başlamaktadır. 
Yaş dönemleri arasındaki farklılıklarda dikkat çekici olan yaş büyüdükçe kadınlık ve erkeklik arasındaki değer farkının da algılanır olmasıdır. Küçük yaşta net olan ayrım daha az hiyerarşik olarak algılanmakta, yaş büyüdükçe kadınlık ve erkeklik arasındaki değer farkı da algılanır olmaktadır. Özellikle ergenler kadınlık rollerinin ikincilliğini fark etmekte ve bunun değişmezliğine dair bir görüş taşımaya başlamaktadırlar. Yani bilgi düzeyindeki farkındalıktoplumsal beklentiye bağlı olarak davranışlara yansıyamamaktadır. Bu ikincillik dolayısıyla, kız çocukların toplumsal cinsiyet algısı, erkek çocuklara göre daha yüksektir. Erkekler özellikle kendi rollerine odaklanırken, kız çocukların daha bütünlüklü bir kavrayışa sahip olduğu ve kendi rollerini erkeklerin rolleriyle karşılaştırma içinde değerlendirdiğini söylemek mümkündür. Yaş büyüdükçe daha çok ortaya çıkan bu durum, özellikle genç kızlarda, kendi konumlarının ikincilliğine karşı güçlenebilecek alanlar arama çabasıyla açıklanabilir. Tüm yaş gruplarında "kız /erkek olmaktan memnun musunuz?" sorusu büyük bir oranda olumlu yanıtlanmışken; yine yaş arttıkça, hem kızlar hem erkekler tarafından "erkeklerin yaptıklarının, özelliklerinin daha değerli görülmesi” söz konusudur.

$\mathrm{Bu}$ hiyerarşik değerlendirme için çocuklar tarafından öne sürülen temel gerekçe, erkeklerin kadınlardan daha "güçlü” olduğudur. Erkeklerin fiziksel olarak sahip oldukları -varsayılangücün toplumsal olarak bu denli büyük bir fark yaratması ve tüm meşruiyeti taşıyabiliyor olması şaşırtıcıdır. Bu algı, her yaş grubunda bulunmakta ve sağlıktan spora, ev işinden para kazanmaya her alana yansıyabilmektedir. Çocukların ifadeleriyle bu konudaki bir kaç örnek şöyle:

“ K: Çünkü erkekler böyle daha güçlü doğuyor klzlar hani daha hafif!” (7-8)

“E: Annemiz yorulur babamız dayanıklı olduğu için yorulamaz fazla” (7-8)

"E: Hani mesela ne desem hani o sigara içtikçe akciğerleri şey oluyor ya, zedeleniyor o ee şey erkeklerin kızlarınkine göre bünyesi daha dayanıklı olduğu için kızların kanser olma yaşı daha erken olabiliyor." (9-10)

“K: Şimdi bizim gücümüz yok, hem de erkekler bizi bizden en önce yaptı̆̆ içim bizden daha gayret yapıyorlar; hem erkekler daha güçlü, hem erkekler... Zaten şey topu atıyorlar attıktan sonra boyları uzun oluyorlar boyları uzun oluyor ve çok şey atmaya başlıyorlar ben kesin erkekler yencek diyorum." (9-10) 
“E:Kızların kasları erkekler gibi tam gelişmiş değil. Çok güçlü değiller. Onlara az verilmiş, bize çok verilmiş. Eşit gibi oluyor. (11-12)

"K: Erkekler kendilerini koruyabiliyor, kızlar yapamıyor. (13-15)"

Alıntıların da gösterdiği gibi, kadınlar ve erkekler arasındaki fiziksel güç farkı, çocuklar açısından erkeklerin yapabildiği ve kadınların yapamadığı her şeyi açıklamak için yeterlidir. Bir sonraki kategori olan cinsiyete dayalı işbölümünde, bu algılayışın toplumsal sonuçları daha net olarak görmek mümkündür.

\section{Toplumsal işbölümü, Eviçi emek ve Çalışma / meslek tercihleri}

Toplumsal işbölümü söz konusu olduğunda, erkeklerin fiziksel üstünlüğüne bir de kadınların doğurganlığı eklenmektedir. Bu iki biyolojik durumdan hareketle, tüm yaşlar için hem ev içi iş bölümü hem de meslek ayırımı çok net olarak cinsiyetçi biçimde ortaya çıkmakta ve bu yolla meşrulaştırılmaktadır. Bu kategoride sorulan "anne para kazansa, baba evde çocuklara baksa nasıl olur?" şeklindeki "kışkırtıcı" soru, istisnasız tüm çocuklar tarafından reddedilmiş; hatta çocukların bir kısmı böyle bir durumu "saçma sapan”, "tuhaf”, "abes” gibi güçlü tepkiler vererek, böyle bir ihtimali temelden yok saymışlardır.

$\mathrm{Bu}$ güçlü reddiyenin altında yatan, aslında görmeye alışı olmadıkları için çocukların ne babalarına çocuk bakmayı, ne annelerine evi geçindirmeyi "yakıştıramıyor" olmalarıdır. Görüşlerinin meşruiyetini ise fiziksel "yapabilirlikte” bulmaktadırlar. Çocuklara göre babalar çocuk bakamaz; anneler ise evi geçindiremezler.

“K:Bence ikisine de yapabileceği işler veriliyor. Erkekte güç diye bir şey var. Erkekler daha güçlü oluyor, yapı bakımından doğduğundan itibaren. Erkekler güçlü olduğu için daha çok çalışmaya yönelik çalışıyor kafaları. Ev hanımlığı yapayım, terbiye vereyim demiyor." (11-12) 
"E:Kızlar, erkeklerden daha iyi anllyor bebekleri mesela. Onların kanından doğdu ya ne yapacă̆ını hemen anlıyor. Farklı farklı yollar deniyor çocuğu doyurmak için. Kızlar hemen anllyorlar ne istediğini." (11-12)

"E: Mesela benim babam muhasebeci, annem muhasebeciliği kaldıramaz

Soru: Neden?

“E: Babam yük taşıyor annem taşıyamaz!”(9-10)

“K: Annelerin çalışması daha kötü. Baba çalışsın. Çünkü şu yüzden, erkekler kendilerini koruyabilirler dışarıda ama kadinlar koruyamazlar."(13-15)

"K: Bir şey diyece ğim, büyük ağabeyler ve babalar yemek yapamaz çünkü onlar klz işlerini yapar, gülerler belki ama küçük kızlar annelerine yardım edebilir."(7-8)

Anneler (kadınlar) dışarıda çalışsa bile, evdeki işleri yapma yükümlülüğü de onların üzerinde görülmektedir. Kendi yaşamlarında gördükleri örnekler de bu yönde olduğu için, babaların arada bir mutfağa girmesi bile önemli karşılanmaktadır. Çocukların verdikleri örnekler, babaların çoğunlukla anne hastayken, nadiren isteyerek ev işi yaptığını göstermektedir. Babaların isteyerek yaptığı işler çocuklar tarafından “zor, güç isteyen” işler olarak tanımlanıyor olmasıdır.

"E:Bazı babalar eşlerine yardım ediyorlar, mesela o hastalandı diyelim bir şeye ihtiyacı var o biraz diyor ki sen biraz otur diyor ben de yapabilirim diyor o yapıyor, o bazen de yemeği yapıyor." (9-10)

“K:Benim babam zor iş olduğu için zaten ütü yapıyor. Çünkü o pantolonlara falan bayağı dikkat eder. Çift ütü izi olmayacak mesela pantolonda. Onun için anneme asla güvenmez yani o konuda. "(11-12) 
Bu bakış açısına bağlı olarak, elbette kadınların ve erkeklerin yapabilecekleri meslekler de cinsiyet rollerine uygun olmalıdır çocuklara göre. Bu nedenle tehlikeli ve ağır işler erkeklere uygun görülürken, daha kolay işlerin kadınlara uygun olduğunu düşünen çocuklar çoğunluktadır.

"E1:Ama kolay işlerde çalışıyor. Emlakçılarda oturuyorlar, gelip veriyorlar. Sekreterler de güzel konuştukları için çekiyorlar insanı."

“E2: Garsonluk da güzel yemekler yapıyorlar. Ondan olabilir. Öğretmenlik olabilir. Güzel bir meslek. Ama mesela ev yapanlar hep erkeklerdir.” (11-12)

Bununla birlikte mesleklerin, çevrelerinde ve özellikle televizyonda farklı meslekler yapan kadınlar gördükleri için, cinsiyetçiliğin en fazla kırıldığı alan olduğu söylenebilir. Bunda annelerin özellikle kız çocuklarına yönelik yaklaşımlarının da rol oynadığını söylemek gerekir. Kendisi okumamış olan ve bunun zorluğunu -muhtemelen- kocasıyla ilişkisinde sıklıkla yaşayan anneler, kız çocuklarının okuyup meslek sahibi olması için çaba harcamaktadır. Son iki alıntı bu konuda yorum yapabilmek için veri vermektedir.

K: "Benim annem şimdi çok pişman liseye kadar geldi sonra üniversiteyi okumadı, çok pişman diyor ki ben senin yerine olsaydım valla diyor üniversiteyi de bitirirdim çok güzel bir iş sahibi olurum diyor, biz bazen mesela sıklllyoruz ders çalışmaktan annem bazen diyor ki kızım ders çalış bak benim gibi pişman olma diyor, ondan sonra beni ders çalıştırıyor. "'(9-10)

K: "Kızlar okusun kendi iyilikleri için ama bir yönden de şöyle, kocalarıla boşandıkları zaman kendi ayaklarl üzerinde dursunlar. Bir meslekleri olsun."(13-15)

K: "Yani okuduysa diyelim, bir öğretmen, bir doktor veya da bir meslek varsa iyi olur. Ama mesela bir mesleği yoksa gidip de bir mağazada çalışmasın. O zaman zaten erkekler izin vermiyor. Bir meslek sahibi olduğu zaman izin veriyorlar. O daha iyi oluyor. "(1315) 
Yine de, ne meslek yapıyor olurlarsa olsunlar, toplumsal işbölümü içinde erkeklerin yaptıkları ve varlıkları, kadınlardan daha değerli görülmektedir. Çocukların gözünde erkek, kadın çalışıyor olsa bile hep daha fazla çalışandır. Eşit para kazanıyor olsalar bile, evi geçindirendir. Ve ev geçindirmek, evde çocuk bakmaktan çok daha değerli görülmektedir.

“K:Mesela çoğunlukla evin erkeği çalışır didinir. Evin kadını ise çocuğa bakar, çalışıp didinmez. Mesela erkek işten atılırsa aç kalır. ”(13-15)

"K: Gidip kocam benden mi para isteyecek? Asla vermem! Ben utanırım, hem o da utanir. Erkek de gururuna yediremez." (13-15)

Alıntıların her ikisinin de büyük yaştaki kız çocuklardan geliyor olması, bir tesadüf değildir. Annelerin yeniden üretim işlevlerini "başarıyla" yerine getirmelerinin bir sonucu olarak kız çocuklar kendilerini ve annelerini güçsüz, değersiz hatta işe yaramaz görmektedirler. Erkeklerin ve erkekliğe ait olan her şeyin daha değerli görülmesi, çok da şaşırtıcı olmayan biçimde - sadece 13-15 yaş grubuna sorulan- "büyüdükçe kadın olmak mı erkek olmak mı daha zor?” sorusunda, hem kız hem erkek çocukların neredeyse tamamının erkek olmak olarak yanıtlamış olmasında görülmektedir.

“E: Hocam erkekler için zorlaşıyor. Hocam askerlik var, evlilik var, evlenmeden önce ev falan alacaksin onun taksiti var. Öl git daha iyi. "(13-15)

“E: Bazı kızların annesi 'benim kızımı alacak damat, büyük bir evi olacak, arabası olacak' falan diyor. Onlara çabalarken hayat zorlaşıyor.”(13-15)

“K: Erkek olmak zorlaşlyor bence, askerlik varmış, anne babalarının yükü, evlenmek, eve hizmet falan." (13-15)

Aynı biçimde ifade ediyor olsalar da bu görüşlerin kızlar ve erkekler için farklı anlamlar taşıdığını görmek zor değildir. Yine hegemonik erkeklik kavramına geri dönerek, kız çocuklar için değerli olan ama asla ulaşılamayacak bir şeyden bahsettiğimizi hatırlamak gerekir. Kızlar 
ancak bu değerini taktir ve kendi ikincilliğini kabul ettiği sürece o güce yaklaşabilmektedir. Erkekler için ise durum biraz daha karışıktır. Yetişkin oldukça "başarılması gereken” şeylerin sayısının arttığı ve başarmanın zorlaştığı bilgisi ergenlikte erkeklerin sırtına çökmektedir. Hegemonik erkekliğin parçası olamama kaygısı erkek çocukların hayatlarını güçleştirmektedir. Çocukların algısı toplumsal bakışla son derece tutarlı olmakla birlikte, kız çocukların kendi yaşam zorluklarını anlattıktan sonra bu kanıya varmış olmaları cinsiyetçi yaklaşımın ne denli güçlü olduğunu göstermek açısından önemlidir.

\section{Akranlarla ilişkiler/Sevgililik halleri}

Kız ve erkek çocuklar arasındaki ilişkilerin, temel olarak cinsiyet rollerine uygun biçimde geliştiğini söylemek yanlış olmayacaktır. Bunun izlerini özellikle oyunlarda ve ergenlikle daha görünür olan, sevgililik hallerinde izlemek mümkündür.

Oyunlar, yaş dönemine göre değişse de, her dönemde cinsiyetlere göre ayrışmış olması ortak bir özellik olarak görülmektedir. Kızlar ve erkeklere özgü olarak görülen oyunlar çocuklar için çok nettir; evcilik, ip atlama kız oyunu, futbol erkek oyunu olarak görülmektedir. Erkeklere uygun görülen fiziksel aktivitesi yüksek oyunlar, tahmin edileceği gibi erkeklerin daha "güçlü” olduğu varsayımına dayanmaktadır. Bazı çocuklar için bu ayrım çok net ve kesin olarak görülürken, çoğunluğunu kızların oluşturduğu daha küçük bir grup için bu durum değişebilirdir. Yine tahmin edilebileceği gibi meseleye daha keskin bakan çocuklarda ayrımcı, dışlayıcı daha esnek bakanlarda ise sorgulayıcı tutumlarla da karşılaşılmaktadır. Aşağıdaki alıntılar bu katı ve esnek yaklaşımlara dair örnekler içermektedir:

"E1: Açıkçası ben şimdi şey erkeğim diye şimdi kız oyunlarını da sevmiyorum belki şey geliyor ya futbolu çok seviyorum." (9-10)

"K1: Mesela biz oyun oynasak, hemen erkek işi deyip şey yapıyorlardı."

"K2: Biz futbol oynamaya gittiğimiz zaman, çok seviyoruz, şey yapanlar, ters tepki gösterenler oluyor. Bazen hocalardan bile ters tepki aldı̆̆ımız oluyor yani.” (11-12) 
"K: Tamam öğretmenim şimdi şey oldu dedik ya bacaklarımız güçlü değil dedik kollarımız güçlü değil dedik He ama yani onları güçlendirebilmek için sen teknoloji gelişti dedin onları da yapabiliriz, illa ben onu yapamam diye benim onu bırakmam şey değil.” (9-10)

"E1:Onlar nasil futbolu oynayamıyorsa biz de voleybolu oynayamıyoruz.

Soru: Neden peki bu fark sizce? Kizlar neden futbol oynayamiyor?

"E2:Demek öyle yaratmışlar(gülerek)”

"E3:Oynuyor."

"E4:Ayaklarında güç yok.”

"E1:Kızlara göre değişiyor."

“E5:Bizim de elimizde mi güç yok?” (11-12)

“E1: Kızlar topa ayakla vuramadığı için elle vuruyorlar. Ondan.

“E2: Ama alışmadıkları için. Biz küçükken hep top oynuyoruz, alışıyoruz.” (13-15)

Yukarıda bahsedilen erkekliğin daha değerli olma halinin, oyunlarda da bir karşılığı olduğu görülmektedir. Yapılan görüşmelerin hiçbirinde kızların oyunlarına özendiğini ifade eden bir erkek çocuk bulunmazken, kız çocukların hemen yarısı erkeklerin oyunlarına dahil olma isteklerini dile getirmişlerdir. Ayrıca erkeklerle oynamak isteyen kızlar genel olarak destek görürken; kızlarla oynayan erkekler özellikle erkekler tarafından küçük görülmektedir:

"K: Erkeklerin oynadığı oyunlar daha eğlenceli. Kızlar ip atlıyor, erkekler top oynuyor.” $(13-15)$

"K: Biz erkeklerin oynadığı oyunları oynamak istiyoruz, onlar bize öğretiyor. Ne bileyim, şişe çevirmece, doğruluk mu cesaret mi gibi oyunlar, erkeklerle bir araya geldiğimizde saklambaç, ebelemece, yerden yüksek gibi oyunlar güzel oluyor.” (13-15)

“K: Erkekler bizi sınıftaki kızları ayırıyor. Bizim sınıfta da var kızlarla oyun oynayan bir erkek arkadaşımız. Ona kötü davranıyorlar. Ona biraz kız gibi davranıyorlar.”

Soru: K1z gibi davranıyorlar derken nasıl davranıyorlar?

“K: Onun arkasından konuşuyorlar. Gay falan..." (11-12) 
Çocukların en temel sosyalleşme ve öğrenme araçlarından olan oyunların bu denli cinsiyetçi bir yapıda olması, çocuklar tarafından da böyle algılanıp kullanılması, beklendik ama düşündürücü bir durumdur. Oyunların daha eşitlikçi bir yapıya evrilmesi; kız erkek birlikte oynanan - mesela araştırmada görüşülen çocuklar açısından bu voleyboldur- oyunların yetişkinler tarafindan özendirilmesinin çok önemli olduğu görülmektedir.

Akranlarla ilişkilerde cinsiyetçiliğin zirve yaptığı alan, sevgililik halleridir. Çocuklardaki genel toplumsal cinsiyet algısına en doğrudan karşılık gelen alan da bu olmuştur. 6-7 yaş grubunda ikili ilişkideki roller çok nettir. 9-10 yaş grubunda, kız erkek "arkadaşlık" ilişkisinin zayıf olduğu, birbiriyle vakit geçirmekten hoşlanmanın en alt düzeyde olduğu görüldügü halde, ikili ilişkilere dair en esnek bakış açısıyla yine bu yaş grubunda karşılaşılmıştır. Ergenlikle birlikte roller keskinleşmekte ve toplumsallaşmanın da etkisiyle cinsiyetçilik artmaktadır. Tüm yaş gruplarına sorulan "kızlar erkeklere evlilik / çıkma teklif edebilir mi?" sorusuna verilen yanıtlar bu açıklamayı örnekleyecektir.

"Soru: Kizlar erkeklere evlenme teklif edemez mi?

"K1: Hayır çok karışık olur."

“K2: (gülerek) Kendi yüzüğ̈̈nü kendisi alıyor, kendisine takıyor! Öyle olur mu hiç!”(7-8)

"E: Aslında daha çok böyle kız gidip erkeği istemesini görürsek ĕger ona da alışabiliriz.” $(9-10)$

"K:Ama kızlar daha narin olduğu için çıkma teklifi etmezler. Erkeklerin kalbi falan kırllmaz. Reddedilse o 1-2 dakikalık bir şey olur yani. "(13-15)

Bu soruya verilen yanıtlarla ilgili dikkat çekici bir başka nokta, erkeklerin bu konuda kızlardan daha "açık fikirli” olmalarıdır. Kızların, belki de "namus" algısıyla ilişkili olarak, kendilerine yüklenen cinsiyet rollerinin dışına çıkmaktan kaçındıklarını görmek, olumsuz bir durum olarak işaretlenebilir. 
Çocukların ifadelerinden çıkan çok önemli bir başka saptama kız ve erkek çocuklar arasındaki ilişkilerin arkadaşlıkta nispeten daha eşitlikçi; sevgililikte tamamen cinsiyetçi olarak ortaya çıkmasıdır. Sevgililik halinde erkekler katı bir korumacılık içine girmekte, kızlar ise kontrolcü ve bazen de anaç bir tavır sergilemektedir.

"K: Ben mesela erkek arkadaşımın arkadaş çevresine karışırım. Çünkü onu eğer kötü yola saptırıyorsa, istemem onunla görüşmesini.” (13-15)

“E: Mesela hocam kızla oturuyorsun ya, başka bir kız geçiyor, yanındaki kız hemen "bakma” falan diyor."(13-15)

“K: Yani erkeklerde sahiplenme duygusu var. Bir de şey var. 'Ya o benim sevgilim, kimse bakamaz, klsa etek giydiğinde gelir bana söylerler' falan. Bir de erkeklerde koruma duygusu oluyor ya. O yüzden işte sürekli ‘yapamazsın, edemezsin’ diyorlar.” (13-15)

"E: (erkeğin) sorumlulukları var. Mesela korumak, laf ettirtmemek.” (13-15)

“K: Saçımızı biraz güzel yapsak saçını öyle yapmayacaksın. Oyun oynayıp konuşsak, onunla oynamayacaksın, konuşmayacaksın. Biz bir kızla konuştuğunda kızıyoruz ama onlar her şeye klzıyorlar. Yanında oturan erkeğe, sınıfta konuştuğun erkeğe, giydiğin etek. Her şeye karlşlyorlar." (13-15)

$\mathrm{Bu}$ durumun ortaya çıkardığı daha da olumsuz sonuç, erkeklerin zaten içinde bulundukları ve çok da şikayetçi olmadan benimsedikleri şiddet davranışlarını sevgilileri üzerinde uygulama "hakkını" kendilerinde görmeleridir. Fiziksel şiddet örneği gelmemiş olmakla birlikte, fiziksel şiddet tehdidi ve sözel şiddetin varlığıyla sıklıkla karşılaşılmıştır. Aşağıdaki iki örnek, durumun vahametini anlamak için yeterli olacaktır:

"K:Mesela bir şey dedin mi hemen kavgaya bağllyorlar. Hemen döveceğim, pataklayacağım."(11-12)

“E: Manitam olursa hocam, ăgı, burun girerim ona da, öyle mini etekle gezerse hocam..."(13-15) 
Akran ilişkilerinde açıkça ortaya çıkan, arkadaşlık ve sevgililik ilişkileri arasında kız ve erkeklerin davranışlarında önemli farklar olması, bunların çocuklar tarafından benimsenerek açıkça dile getirilmesidir. Sevgililik hali erkeklerdeki korumacı, kızlardaki itaatkar ve anaç rolü arttırarak onları yetişkinliğe hazırlamaktadır. Aslında her iki cinsiyet için de büyük zorluklar taşıyan bu roller, görüldüğü kadarıyla erkekler tarafından memnuniyetle kabul edilmekteyken, kızlar ise daha şikayetçi görünmekte ancak bunu dönüştürecek gücü de kendilerinde bulamamaktadırlar.

\section{Tartışma: Çocuklarda Toplumsal Cinsiyet Eşitliği Algısı Oluşturmanın Olanakları}

Çocuklar toplumsal cinsiyet rollerini çevrelerinden öğrenmekte ve kendi yaşamlarında uygulayarak sabitlemektedirler. Kendi cinsiyetine ait rolleri yerine getirdikçe ödüllendirilen çocuk, yetişkinliğe gelene kadar cinsiyet rollerini öğrenmiş olur (Tobin ve ark., 2010). Küçük yaşlarda çevreye uyum sağlamak amacıyla edinilen toplumsal cinsiyetçi davranışlar, yaş büyüdükçe onları zorlamaya başlasa da giderek değiştirilemez olarak görülmektedir. $\mathrm{Bu}$ araştırmanın bulguları da toplumsal cinsiyet rolü algısının yaş dönemlerine göre farklılaştığını göstermektedir. Küçük yaşta cinsiyetçi rollere dair net olan algı ergenliğe doğru esnemekte, ancak ergenlikle birlikte cinsiyetler arasındaki hiyerarşik farkları da içerecek biçimde tekrar eski kesinliğine dönmektedir.

Araştırmanın ortaya koyduğu önemli bir sonuç da, özellikle ergenlerde görülen ve her iki cinsiyet tarafından da paylaşılan erkek olmanın daha değerli görüldüğü algısıdır. Bu yüzden kızlar kendi rollerini karşı cinsiyetin rolleriyle daha fazla kıyaslamakta ve "eksikliklerini" kabullenmek için gerekçeler, azaltmak için de direnme mekanizmaları oluşturmaktadırlar.

Farklı çalışmaların da ortaya koyduğu gibi ayrımcılıktan daha mustarip olan kız çocuklar, durumu eşitlemenin yolunu eğitimlerine devam etmekte ve bir meslek sahibi olmakta görmektedirler. Özellikle anneler kızlarını bu yolda teşvik etmektedirler. Ancak ne annelerin ne de kızların, eşitsizliğin yaşandığı ve öğrenildiği ilk alan olan ev içindeki cinsiyete dayalı 
işbölümünü değiştirmeye, dönüştürmeye yönelik herhangi bir algıya sahip olmadıkları görülmüştür. Kadının doğurganlığı bu alanda herhangi bir değişim olabileceğine dair olasılıkları ortadan kaldırmaktadır. Genç kızlardaki bu algı, büyük ölçüde - onların ifadesiyleannelerinin tutumlarından kaynaklanmaktadır. Annelerin tutumu ise eğitim düzeylerinden bağımsız olarak, çocukluklarında onlara yüklenen cinsiyet rollerinin etkisiyle ortaya çıkmaktadır. Bu roller öyle güçlüdür ki, eğitim seviyesi daha yüksek olan annelerin çocukları, cinsiyet rollerine dair daha fazla kalıpyargılara sahiptir (Bağçeli, 2008). Bu durum, eğitim sisteminin de kalıpyargıları destekleyici olduğuna kanıt olarak gösterilebilir. O halde ilk olarak söylenmesi gereken, toplumsal cinsiyetçi sistemde daha fazla eziliyor olan kadınların ve kız çocukların güçlenmesinin, farkındalıklarının artmasının çok temel olduğudur.

Erkekliğin daha değerli görülmesine bağlı olarak, kız çocukların erkek özelliklerine “özenmesi” veya sahip olması çocuklar tarafından kabul edilirken; kadınsı özellikler taşıyan erkek çocuklar, özellikle diğer erkek çocuklar tarafından şüpheyle karşılanmakta hatta aşağılanmakta, dışlanmaktadır (Schmalz ve Kerstetter, 2006). Erkeğin, “erkek gibi” olması bir toplumsal kabul koşulu haline gelmiştir. "Erkek gibi” olmak ise basit biçimde "güçlü” olmakla özdeşleşmektedir. Çocuklar açısından "güç" çok net olarak erkeklere özgü bir şeydir ve hemen her zaman -somut düşüncenin bir zorunluluğu olarak- fiziksel güç olarak anlaşılmaktadır. Oysa fiziksel olarak güçlü olmayan ya da daha yumuşak, daha sakin olduğu için "kı gibi” olmakla suçlanan erkek çocukların sayısı hiç de az değildir. Hegemonik erkeklik algısından beslenen bu katı, cinsiyetçi kategorileşme pek çok erkek çocuk için ayrımcı sonuçlar yaratmaktadır.

Ayrıca evi geçindirme sorumluluğunu tek başına omuzladığı düşünülen erkekler için, yetişkinliğin de daha zor olduğu düşünülmektedir çocuklar tarafından. Bu sorumluluğun 13-15 yaşındaki erkek çocukları şimdiden düşündürdüğü, tedirgin ettiği odak görüşmeler esnasında gözlenmiştir. Kısaca erkekler de bu cinsiyetçi sistemden zarar görmekte, ancak sistemin çocukların ifadesiyle- "üstün” tarafı oldukları için bu zararın karşılığını almaktadırlar. Bu nedenle yapılacak araştırmaların ve her tür çalışmanın erkeklerin toplumsal cinsiyetçi sistemden gördükleri zararları açığa çıkarmaya ve onlardaki farkındalığı arttırmaya yönelmesi de önem taşımaktadır. Her yaş grubundan erkekle, hegemonik erkekliğe dair daha fazla araştırma yapılmasına büyük ihtiyaç vardır. 
Özetle, çocuklar açısından cinsiyetçi roller buna bağlı olarak erkekler ve kadınlar arasında ortaya çıkan tüm ayrım, fiziksel güç farkına ve kadınların doğurabilmesine dayanmaktadır. Çocuklar cinsiyetçiliğin her tür "toplumsal" sonucunu bu fiziksel özelliklere bağlı olarak açıklamaktadırlar. $\mathrm{Bu}$ durum çocuklarda toplumsal cinsiyet algısının bulunmadığını, cinsiyetin sadece biyolojik cinsiyet olarak algılandığını göstermektedir. Bu elbette çocukları çevreleyen alanın toplumsal cinsiyet algısının zayıf olduğunun da işaretidir. Çocukların "yetişmesinde" ağırlıklı etki taşıyan aile ya da okul eğitiminin çocuklara böyle bir bakış açısı kazandırmadığı açıktır. Bununla birlikte araştırma, toplumsal cinsiyet eşitliği algısını geliştirmek açısından en avantajlı yaş döneminin 9-11 yaş olduğunu ortaya çıkarmıştır. $\mathrm{Bu}$ dönemde çocukların cinsiyet rollerine dayalı kalıplaşmış rollerin farkında olduğu, ancak bunun dışına çıkılabileceğine dair de bir algıları olduğu görülmüştür. Toplumsal cinsiyet rolüne uygun olmayan bir örnekle karşılaştıklarında küçük yaş grubunda olduğu gibi bunu reddetmemekte ve büyük yaş grubundan farklı olarak bunun yapılabilir bir şey olduğunu düşünmektedirler. "Oyuncak bebekle oynayan erkek çocuk”, "iyi futbol oynayan kız çocuk”, "bebeğine bakan erkek" ya da "inşaat işçiliği yapan kadın” gibi "alternatif” örnekleri gerçek yaşamda ya da medyada gördüklerinde bunun yapılabilir olduğuna dair görüşleri güçlenmektedir.

Çocuklar "öğrenerek" yetişkinliğe hazırlanırlar. Bu nedenle öğrenme alanları ve imkanları genişlediğinde, farklı örnekler, modeller, düşünme sistemleriyle karşılaştıklarında daha fazla alternatif sahibi olacaklar, "olmak istedikleri gibi olma" şansına daha fazla erişeceklerdir. Bu araştırmanın gösterdiği en önemli sonuçlardan biri çocuklar için cinsiyetçiliği “esnetebilecek" noktaların neler olduğudur. Bu noktaları beş başlık altında toparlamak mümkündür:

1) Çocuklar bilgi ve beceri geliştirip deneyim kazandıkça cinsiyetçi ayrımcılıktan uzaklaşmaktadırlar. "Öğrenirse yapar!” düşüncesi kalıpyargıların dışında düşünebilen çocukların sıklıkla ifade ettikleri bir şeydir. Dolayısıyla çocukların karşı cinse uygun olduğu düşünülen farklı etkinliklere yönlendirilmesi, bunun için desteklenmesi önemlidir.

2) Eleştirel düşünme becerileri, diğer her tür kalıpyargı gibi, cinsiyetçi kalıpyargılarla başa çıkmanın da en temel araçlarındandır. Odak görüşmeler içinde bile çocuklara sadece 
"neden?” diye sorulması, konunu üzerine düşünmelerine ve daha esnek görüşlere ulaşmalarına yol açmıştır.

3) Çocukların adalet duygusunun çok güçlü olduğu görülmüştür. Cinsiyetçiliğin hem kadın/erkek arasında hem de kadınların ve erkeklerin kendi içinde yarattı̆̆ı haksızlığı fark etmeleri sistemi kabullenmekten vazgeçmelerini kolaylaştırmaktadır.

4) Farkındalığg artıran en önemli etmenlerden biri, farklı örnekler görmeleridir. Hele bu örnekler kendi yaşamlarından olursa etkisi daha da yüksek olmaktadır. Bu durum "ben de yapabilirim" demelerini sağladığı gibi ayrımcı tutumdan uzak durmalarına da olanak tanir.

5) Kızlar ve erkeklerin birlikte vakit geçirip birlikte üretmeleri sağlayan durumlar da cinsiyetçi kalıpyargıları esnetme olanağı geliştirmektedir. Yüz yüze temas, genellemeye dayalı kalıpyargıların ortadan kalmasını sağlamaktadır. Hatta bunun örnekleri odak görüşmelerde bile yaşanmıştır.

İşin özü, tam da çocuk hakları yaklaşımına uygun olarak, çocukların kendi bireyselliklerini geliştirmelerine olanak sağlamaktır. Böylece içine sıkıştırıldıkları kalıpyargıları esnetmek için bir şansları olabilir. Toplumsal cinsiyetçi kalıpyargıların kırılması, çocukların sırf cinsiyetlerine göre davranmak zorunluluğu hissetmeden özgürce yaşayabilmesi, daha özgür öğrenme ve üretme ortamlarına kavuşmalarıyla mümkündür.

Bütün bunlar göz önünde bulundurulduğunda, çocuklarının yaşamlarının önemli kısmını geçirdikleri okulun ve eğitim sisteminin çok büyük önem taşıdığı açıkça ortadadır. İşin tuhafı, odak görüşmeler boyunca çocuklar arkadaşlarıyla ilişkileri dışında okulun cinsiyet algılarına etkisinden hiç bahsetmemişlerdir. Oysa yukarıda sayılan ve cinsiyetçi kalıpyargıları esneteceği iddia edilen tüm araçlar, okulda ve eğitim sistemi içinde etkin olarak kullanılabilecek araçlardır. Okul aracılığıyla ev içine ve çocuklar arasındaki arkadaşlık ilişkisine doğrudan müdahale edebilmek mümkündür. $\mathrm{Bu}$ nedenle toplumsal cinsiyet eşitliğine yönelik yeni araştırma ve çalışmaların okullara odaklanması araştırma ekibi tarafından önemli görülmektedir.

Bir diğer önemli alan medyadır. Araştırmada medyanın cinsiyetçilikle mücadele konusunda etkisine dair en temel örnek, farklı kadınlık ve erkeklik durumlarının çoğu zaman medya aracılığıyla görünür olmasıdır. Bebek bakan erkek, halter kaldıran kadın gibi çocukların 
kafasındaki cinsiyet rollerine aykırı eylemlerde bulunan kadın ve erkekleri hem de tüm hanelere ulaşarak gösterebilecek en güçlü araç olarak medyanın etkisi önemsenmelidir.

Öte yandan, bu araştırmanın bulguları eğitsel ve sosyal alanda yapılacak çalışmalara da destek olabilir. Özellikle bulguların çocuk gelişimi ile uyumu dolayısıyla, geliştirilecek her tür eğitim aracında/materyalinde, yukarıda bahsedilen esneme noktalarının dikkate alınması yararlı olacaktır. Sadece cinsiyetçi kalıpyargılar açısından değil, ayrımcılık yaratan her tür kalıpyargı ile mücadele için anlamlı sonuçlar yaratacağı düşünülmektedir. Çocuklarla yapılan çalışmalar onların bugünü için büyük önem taşımakta, ama aynı zamanda toplumsal dönüşüm için de potansiyel yaratmaktadır. Cinsiyetçilikle mücadele eden çalışmalar, tüm kadın ve erkeklerin olmak istedikleri gibi olmalarına ve çocukların da kendilerini gerçekleştirdikleri bir toplumda yetişmelerine olanak sağlayacaktır.

\section{Summary}

Gender roles and stereotypes are social constructs that influence children's perception of sexual identity which shape a child's developmental sexual properties. To create an educative play for improving children's gender perceptions; data from 66 students between age 7 to 15 was collected using a scale adopted from BEM Inventory. Children were expected to express gender ideas about social and house labor division, play and free time activities, work and job preferences, in-school behaviors, relationship with teachers, peers and partners.

Results showed rigidity of gender roles and flexibility of children by age. Flexibility of gender roles appeared in a curvilinear shape between age 6 to 15. It appears most flexible at age 9, but with adolescence it becomes more rigid. Feminine characteristics are regarded as secondary value in these years. Again at age 9-10, intimate relationship between sexes is distant while during adolescence it becomes closest where boys appear more protective and girls more fragile.

Both genders perceive male aspects as more valuable especially during adolescence. Girls compare their roles with boys more often and attempt to find reasons for their 'inferiority' while 
developing ways of resilience. One such example for the girl child is being succesful at school. Girls mention mother's reinforcement for success at school as themselves have become dependent due to lack of education. Still, division of labor is gender biased regardless of age. Women responsible with house-work and child care and men responsible with family income even when women work outside the house. Though girls were more aware of feminine gender roles' difficulties, all students found more difficult to be a male in adulthood.

Children think men have to be 'a man' and 'powerful'. Biological aspects like being powerful or being able to give birth appear to play an important role in children's justifications and often they are unaware of their gender stereotypes. 9-11 age group reveals as a most convenient age to work with as youngers tend to refuse contrary examples while adolescents do not believe gender differences could change anyhow even if they are unjust.

This research shows 'flexibility points' for gender stereotypes in childhood:

1- The more knowledge and experience they have, the more the children are flexible.

2- Critical thinking skills are influential to cope with gender stereotypes.

3- Being 'just' is important for children. Becoming aware of injustice of gender stereotypes may ease refusal of them.

4- Children should meet different examples against gender stereotypes if possible from their own environment.

5- Situations that provide for boys and girls to work and play together provide room for flexing the gender stereotypes.

With these as a starting point, we developed board games aiming at flexing gender stereotypes of children in different spheres of life like school, home, neighbourhood and private life. We advise the points above to be considered when developing gender equality materials for children. The flexibility points above also show school might play an important role in decreasing gender inequalities. Hence we suggest further research concerning school's role in flexing gender stereotypes. 


\section{KAYNAKÇA}

BAĞÇELİ, P.

2008 Köyde ve Kentte Yaşayan 7-8 Yaş Arası Çocukların Cinsiyet Kalıpyargıları ve Cinsiyete Bağlı Oynadıkları Oyun ve Oyuncaklar, Yayımlanmamış Yüksek Lisans Tezi, Uludağ Üniversitesi Sosyal Bilimler Enstitüsü, İlköğretim Anabilim Dalı, Bursa.

BANSE, R.

2010 "The Development of Spontaneous Gender Stereotyping in Childhood: Relations to Stereotype Knowledge and Stereotype Flexibility”, Developmental Science, 13( 2).

BANDURA, A.

1991 "Sociocognitive Theory of Human Adaptation: A citation-classic commentary on social-learning theory", Current Contents/Social \& Behavioral Sciences, 38 (10).

BEE, $\mathrm{H}$.

2007 Developing Child, Boston: Pearson Education, Inc.

BROWN, C.S.

2004 “Children's Perception of Gender Discrimination”, Developmental Psychology, 40 (5).

BUTLER, J.

1990 Gendertrouble: Feminisim and the Subversion of Identity, New York: Routledge.

CHAMBERS, S. A.

2007 "Sex and the Problem of the Body: Reconstructing Judith Butler's Theory of Sex/Gender", Body \& Society, 13 (47) .

CHODOROW, N.

1974 "Family Structure and Feminine Personality", iç. Women, Culture and Society, (der. M. Zimbalist Rosaldo \& L. Lamphere) California: Stanford University Press.

CONNELL, R.W.

1998 Toplumsal Cinsiyet ve İktidar. (çev. C. Soydemir). İstanbul: Ayrıntı Yayınları.

GİLLİGAN, C.

1987 “Woman's Place in Man's Life Cycle”, iç. Feminisim and Methodology, (der. S. Harding) Indiana: Indiana University Press.

MARTIN, C. L.

2004 "Children Search for Gender Cues: Cognitive Perspectives on Gender Development", Current Directions in Psychological Science, 13 (2). 
NEFF, K.D.

2007 “Children's and Adolocents' Developing Perceptions of Gender Inequality", Social Development, 16 (4).

ÖZDEMİR, E.

2006 Okulöncesi Dönem Çocuklarının Cinsiyet Özelliklerine İlişkin Kalıpyargılarının İncelenmesi, Yayımlanmamış Yüksek Lisans Tezi, Ankara Üniversitesi Eğitim Bilimleri Fakültesi, Ankara.

SANCAR, S.

2009 Erkeklik: İmkansız İktidar, İstanbul: Metis Yayınları.

SCHMALZ, D.L.

2006 “Girlie Girls and Manly Men: Children's Stigma Consciousness of Gender in Sports and Physical Activities", Journal of Leisure Research, 38 ( 4).

SIGNORELLA, M. L.

2008 "Interrelations of Gender Schemas in Children and Adolescenta: Attitudes, Preferences and Self-Perceptions”, Social Behavior and Personality, 36 (7).

SINNO, S. M.

2009 "Moms at Work and Dads at Home: Children's Evaluations of Parental Roles", Applied Develeopment, 13 (1).

THEIMER, C. E

2001 "Young Children's Evaluations of Exclusion in Gender-stereotypic Peer Contexts", Developmental Psychology, 37 (1).

TOBIN, D. D.

2010 "The Intraphysics of Gender: A Model of Self Socialization", Psychological Review, $117(2)$.

TORUN, Y.

2002 GenderBias in Student-Teacher Interaction and its Effect on Reproduction of Gender Roles in the Classroom, Yayımlanmamış Doktora Tezi, ODTÜ, Ankara.

TURNER, K. L.

2007 "The Centrality of Gender and Ethnic Identities across Individuals and Context", Social Development,16 (4).

YOGEV, Ş. P.

2006 Ergenlerde Toplumsal Cinsiyetin Kazanılması: Aile, Okul ve Arkadaş Etkisi, Yayımlanmamış Yüksek Lisans Tezi, Ankara Üniversitesi Sosyal Bilimler Enstitüsü, Ankara. 